\title{
Chartres, 8 rue de Varize
}

$\mathrm{n}^{\circ} 064545$

Dominique Joly

\section{(2) OpenEdition}

\section{Journals}

Édition électronique

URL : http://journals.openedition.org/adlfi/13964

ISSN : 2114-0502

Éditeur

Ministère de la culture

Référence électronique

Dominique Joly, "Chartres, 8 rue de Varize », ADLFI. Archéologie de la France - Informations [En ligne], Centre, mis en ligne le 23 janvier 2015, consulté le 30 avril 2019. URL : http://journals.openedition.org/ adlfi/13964

Ce document a été généré automatiquement le 30 avril 2019.

(C) Ministère de la Culture et de la Communication, CNRS 


\title{
Chartres, 8 rue de Varize
}

\author{
$\mathrm{n}^{\circ} 064545$
}

\section{Dominique Joly}

Lien Atlas (MCC) :

http://atlas.patrimoines.culture.fr/atlas/trunk/index.php?

ap_theme=DOM_2.01.02\&ap_bbox=1.460;48.427;1.550;48.469

1 Un projet immobilier prévoit la construction de trois maisons d'habitation sans sous-sol, sur une parcelle qui comportait des bâtiments construits sur une sorte de replat aménagé dans le terrain naturel. Seul un petit tertre dominait le reste du terrain d'une hauteur de $2 \mathrm{~m}$. Le diagnostic a porté sur cette légère éminence. On y a réalisé une tranchée en équerre, profonde de $1 \mathrm{~m}$. Cette tranchée correspond au tiers de la surface à détruire (soit $50 \mathrm{~m}^{2}$ d'observations). Aucun vestige antérieur à la période contemporaine n'a été repéré ; le terrain naturel, sous forme d'argile orangée à silex, apparaît à un mètre de profondeur.

2 La rue de Varize, située à la limite des quartiers Saint-Vincent et Saint-Lubin, se trouve sur le plateau dominant la rive gauche de l'Eure. Cette voie fut percée au $\mathrm{XIX}^{\mathrm{e}} \mathrm{s}$. en entaillant le coteau.

3 De plus, ce terrain est situé à moins de $10 \mathrm{~m}$ du site des Comtesses (28.085.156 AH) sur lequel ont été mis au jour, en 1999, une nécropole attribuée au VII ${ }^{\mathrm{e}}$ s. et un ensemble de structures modernes appartenant au couvent des Capucins de Chartres. 
INDEX

Index géographique : Centre, Eure-et-Loir (28), Chartres

Mots-clés : tertre, nécropole

operation Évaluation archéologique (EV) 